\title{
BLURRING THE MARGINS: ARDALÉN (2012) AND COLLECTIVE MEMORY IN SPAIN
}

\author{
SARAh Dibble Harris \\ sharris@bennington.edu \\ Bennington College
}

Recibido: 14-12-2016

Aceptado: 14-05-2017

\begin{abstract}
() (1)
RESUMEN

La novela gráfica Ardalén (2012) de Miguelanxo Prado se titula con una palabra inventada por su autor, pero que se refiere a un fenómeno verdadero: un viento de larga distancia que lleva el olor de la sal y del mar lejos de la costa al interior del país. En la novela gráfica, esta brisa marina lleva consigo no sólo sus aires y sus olores, sino también historias, recuerdos, así como criaturas marinas vivas. Apropiado a su título, este libro ganador del Premio Nacional de Cómic de 2012 borra fronteras entre lo real y lo imaginario, entre persona y colectividad, entre tierra y mar, y entre vida y muerte. Los márgenes borrosos existen metafóricamente en la historia del libro, así como visualmente en sus imágenes, tanto dentro de sus viñetas como en los espacios entre sus viñetas. Basándose en el reciente análisis de Anne Whitehead sobre los modos de inscripción y la memoria colectiva, el presente artículo explora la representación de la memoria y lo fantástico en la novela gráfica Ardalén de Miguelanxo Prado, señalando las fuertes implicaciones de la incapacidad del protagonista en Ardalén de distinguir entre lo que vivió y lo que oyó contar en el contexto de la Recuperación de la Memoria Histórica en el siglo xxI de España.
\end{abstract}

Palabras Clave: Miguelanxo Prado, Ardalén, memoria, cómic, memoria colectiva, memoria histórica

\section{Abstract}

The title of Miguelanxo Prado's Ardalén is a word invented by its author, but which refers to a real phenomenon: a long-distance wind that carries the scent of salt and sea far inland from the coast. In the fictional tale, this sea breeze carries with it not just air 
and smells, but also stories and memories, as well as living sea creatures. Appropriate to its title, this winner of the 2012 National Spanish Comics Prize blurs lines between the real and the imaginary, between self and other, between land and sea, and between life and death. Blurred margins exist metaphorically in the book's story as well as visually in its images, both within its panels and in its gutters. Drawing on Anne Whitehead's recent discussion of modes of inscription and collective memory, this article explores the representation of memory and the fantastic in Miguelanxo Prado's 2012 graphic novel Ardalén, noting the strong implications of Ardalén's main character's incapacity to distinguish between what he lived and what he heard in the context of the Recovery of Historical Memory in Spain's early $21^{\text {st }}$ century.

Key words: Miguelanxo Prado, Ardalén, memory, comic, colective memory, historical memory

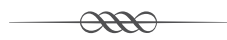

\section{INTRODUCTION}

In a 2009 interview with the US-based Comic Book Resources, Spanish cartoonist Miguelanxo Prado explained his intentions in creating complex narratives by saying, "I'd like to think that the reader is an intelligent person who doesn't need, nor expects, the telling of a simple story with evident personalities, good or bad [...so...] the work that I'm presenting to this hypothetical reader has a level of complexity» also evident in many other mediums (Khoury; 2009, np). Prado's 2012 graphic novel Ardalén certainly establishes this type of nuanced characters, and adds further complexity by blurring lines between the real and the imaginary, between self and other, between land and sea, and between life and death. Blurry margins exist metaphorically in the book's story and also visually in its images, even within single pages or panels. Meanwhile, the ever mysterious past returns to the present in the form of music and sounds, water, winds, mementos, maps, and ghosts.

Prado is the only Spanish cartoonist to have multiple books included in 1001 Comics You Must Read Before You Die, just one indication of his international influence (Gravett, 2011: 511, 577). This particular recognition came before Prado published what is arguably his best work to date, the aforementioned Ardalén. Winner of Spain's National Comics Prize, this book centers on the platonic relationship between two characters. Sabela is a woman in per- 
sonal crisis; newly divorced and unemployed, she travels to a small town in Galicia in search of information about her recently deceased grandfather. There, she meets Fidel, an elderly man whom the townspeople call El Náufrago (The Castaway), and who may have met Sabela's grandfather during travels to Cuba. Unfortunately, Fidel's memory fails him often, and he has trouble distinguishing between what he has experienced personally, what he imagined, and the tales he has heard. His incapacity to distinguish between what he lived and what he heard carries strong implications in the context of historical memory in Spain and collective memory more broadly, especially at the time of the book's creation.

To Sabela's request for information, Fidel protests:

Los recuerdos, que son muchos, van y vienen, sin que yo consiga colocarlos. Nunca estoy seguro de qué sucedió antes o después, me bailan los nombres, las caras... Es como si el libro de mi vida allá se hubiese deshecho y me quedara en las manos un puñado de hojas que no consigo ordenar de nuevo. A veces, incluso, es como si esos recuerdos no fuesen míos... Ni siquiera estoy seguro de diferenciar lo que he vivido y lo que he imaginado. (Prado, 2012: 37)

Fidel's reference to memories as written words on the page, whether in a bound book or his image of disorganized loose-leaf pages, carries the weight of centuries of philosophizing on what memory is. Inscription as a support for memory - even a metaphor for memory - dates back to Plato, who described memory as impressions on the wax tablet of the soul (Whitehead, 2009: 10). There are at least two aspects to this idea: one is the metaphor of the mind as a writing surface onto which memories are imprinted, and the other is the power of actual writing: "[T]he issue of who gets to write in the first place, and who is then subsequently absorbed into the archive, is profoundly marked by gender, as well as by class and race» (Whitehead, 2009: 10). Echoing this element of the study of memory, the question of who remembers, and how, is fundamental in Ardalén.

In her introduction to the critical guide Memory, Anne Whitehead explains that ours is an age obsessed with memory. She proposes that technology and quick access to information, alongside massive immigrations and their accompanying tendency to bring nostalgia, have marked the second half of the twentieth century and become major factors for this obsession (2009: 1-2). «Memory,» she notes, «is historically conditioned; it is not simply handed down in a timeless form from generation to generation, but bears the impress or stamp of its own time and culture» (2009: 4). Because of this premise, her 
book traces the history of the concept of memory from the Classical to the contemporary age, noting the influence of early oral cultures that honored mnemonic feats, through the Enlightenment and Romantic conceptions that emphasized the interrelatedness of self and memory, the nineteenth century and the growth of a subjective subset of history, and the relatively recent focus on the idea of collective memory (2009: 6-8). This article will highlight Whitehead's discussion of modes of inscription and collective memory to explore the representation of memory and the fantastic in Miguelanxo Prado's 2012 graphic novel Ardalén. More specifically, it will argue that Ardalén comments on the impossibility of knowing the truth in memory even when elements of the past insert themselves into the present.

\section{Modes of Inscription: Oral Memory, Objects, and the Written Word}

As an oral process intended to draw out knowledge, and although the written word is also crucial to the book's representation of memory, the practice of Plato's dialectic has resonance in Ardalén. The main character, Sabela, orally interviews Fidel and other characters in an attempt to gather from them reliable information about the past. When it is clear that Fidel's past is confusing and inaccessible, Sabela promises to return to the interview several days in a row in order to give him a chance to remember, or perhaps to invent something that can satisfy them both. Sabela's main path to information, then, is through speaking. She relies on oral interviews in her investigation. She also uses the objects in Fidel's house as touchstones, writes down notes in a spiral notebook, and uses music to spark her interviewee's memory. Derrida has called writing both a remedy and a poison for memory — through writing things down, people no longer have to hold them in their minds, thus diminishing the strength of their 'memorizing muscles' (1981: 109). On the other hand, writing things down also preserves information for the future and potentially makes this information legible for other people.

Putting information into writing for future reference has the added effect of organizing the information in a specific order. Nonetheless, the inclusion of written text does little for Fidel's disorder. Whitehead has reminded us that «In the story of Simonides (...) the two main principles of mnemonics are established: the remembrance of images and the importance of order» (2009: 31). Unfortunately for Fidel, although ghostly images and souvenir objects invade his present day physical space, serving as potential mnemonic devices to access past events, he is utterly unable to order his mental space. In fact, 
one of Fidel's ghostly visitors calls his headspace a «laberinto», and notes that he should use a compass to traverse it (Prado, 2012: 103). Interestingly, in addition to serving as an indicator of Fidel's lack of psychic order, the compass with its «rosa de los vientos», or compass Rose, is also one of the objects in Fidel's house that sometimes acts as a catalyst to spark memories (Prado, 2012: 85, among others).

In addition to his other comment about his memory being like a box of disordered loose-leaf pages, Fidel also loses touch with exactly whose memories these are. Nearly three hundred years earlier, John Locke had highlighted the interrelation between the self and memory when he noted that a person who has lost his or her memory cannot say, «I did that» because "The ' $\mathrm{I}$ ' could not properly be said to stand for the person or the self at that time» (Whitehead, 2009: 57). For Fidel, this certainly seems to be the case, for we are never quite sure who he is: the paradoxical landlocked «Castaway». In many scenes his name is Antonio, and not Fidel at all. Fidel himself complains, «ni yo mismo soy capaz de distinguir sueños y recuerdos en el desbarajuste de mi cabeza» (Prado, 2012: 78) and... «A veces, incluso, es como si [los trozos desordenados de memoria] no fuesen míos... Ni siquiera estoy seguro de diferenciar lo que son imaginaciones y lo que son recuerdos...» (Prado, 2012: 137). To distinguish between these possibilities, we might expect to be able to reference the aforementioned written records. On the written list of crewmembers from the shipwreck that Fidel mentions, Ramón from Spain is reported as having perished, and Antonio from Spain as having survived, but no Fidel appears on the list at all, calling into question Fidel's presence on the shipwreck after which he earned his nickname (Prado, 2012: 141). Sabela's notebook posits that these memories may be from «alguien que se llamó Antonio y que, por caminos extraños e inexplicables, acabó formando parte de su propia memoria» (Prado, 2012: 224). This hypothesis by Sabela exposes one of the fantastic elements in Ardalén: in an otherwise familiar, verisimilar fictional world, Fidel's personal memories don't exactly «belong» to him. Rather, they exist around and within him, often having originated from the experiences of others, and frequently contained in the objects he possesses.

\section{Early Theories of Collective Memory}

The study of collective memory emerged with Maurice Halbwachs's several books on the topic, most notably, his 1950 book The Collective Memory, published in English translation in 1980. Pierre Nora's groundbreaking collec- 
tion Les lieux de mémoire (published in three volumes between 1984-1992) was similarly important in relocating memory beyond just one individual's mind. Halbwachs's theory of practices of memory suggests that memories are never individual: all practices of remembrance, he argues, are shaped socially around such institutions as family, church, and nation. In Ardalén, Fidel has absolutely no living family, a fact that titillates the townspeople, and especially the town troublemaker, Tomás, who comments, "A Fidel no le queda nadie. Somos nosotros, sus vecinos, los que llevamos cuidando de él toda la vida, su única familia... Sus herederos» (Prado: 2012, 51). Tomás's comment is malicious, as he hopes to position himself to inherit Fidel's rumored riches, but it also touches on something apparent throughout this book. As his statement argues, the local bar where this «nosotros» meets does function as a sort of anchoring presence in the lives of the gentlemen who frequent it, possibly as a new version of family for rural areas of Spain depopulated in the aftermath of the post civil war and eventual modernization of the economy. In nearly every scene in the bar, all of the relevant characters are there, drinking, gossiping, and passing time by sharing remembrance or conjecture. Like a functional family, these older gentlemen show commitment to being available for each other, and they practice remembrance together in a dedicated and shared social space.

One could argue, as Pierre Nora did about the modern world more generally, that this non-blood related community, as a substitute for the missing traditional family, is common in our recent times, because old institutions and modes of remembering are evolving. Nora has explained that when modern people feel rupture and loss, instead of dwelling among memories, we now - with intention — create sites to consecrate them. We «must deliberately create archives, maintain anniversaries, organize celebrations, pronounce eulogies, and notarize bills because such activities no longer occur naturally» (Nora, 1989: 12). Nora's notion of lieux de mémoire also informs a consideration of fantastic memory in Ardalén because the bar establishes a collective story for the town, because Fidel's home contains objects meant to induce and maintain memories, and because of the prevalence of facsimiles of documents throughout the book.

Before Nora, Halbwachs had established the essential timelessness apparent in places of ritual by religious and family groups. He argued that collective memory emerges within a specific framework, so that social groups can «enclose and retrieve [their] remembrances» (Halbwachs, 1980: 157) for instance, in a church or a family home, each of which gives the group a sense 
of continuity. In Ardalén, several different spaces, including the mountains, the aforementioned bar, and his inherited home, function for Fidel in this way. The visual representation of the green mountainside specifies Fidel's affiliation to the natural elements specific to his region of residence. Meanwhile, whereas Halbwachs proposes the nation as an important institution for enclosing and retrieving remembrances, nation and nationalism are more layered ideas in the context of Ardalén. While it is outside of the bounds of the current article to go into much detail, it is important to point out that overlapping layers of community identification in Galicia complicate Halbwachs's proposal that spatial borders and institutions permit the practice of collective remembrance. The characters in Ardalén are in Galicia, a province in the northwest corner of Spain, which is itself part of a union of nations of Europe. This multiplicity of identity is reflected in the languages spoken in the province. While nearly all Galicians speak Castilian Spanish, about $80 \%$ also speak Galician, the region's second official language. The use of Galician in schools and other public institutions has increased significantly since the region became autonomous in 1981. Meanwhile, Spain's membership in the European Union since 1986 also adds another layer to the idea of national identity. Of course, the use of languages in the region also carries resonance in the aforementioned context of oral and written record, and specifically, in whose memories are included in written archives, and who can read them. Ardalén debuted simultaneously in Galician and in Castilian Spanish. While Prado's works have been translated into many other languages, and although he reports that he always writes his first drafts in Galician, Ardalén was his first book to be released simultaneously in both Spanish languages. It is also imperative to note that Ardalén's narrative of exile in the postwar was representative of the experience of many Galician men.

\section{Visual Elements as Compass}

Perhaps to provide readers with tools to navigate his complex and layered story, Prado creates a number of visual touchstones. For instance, he uses individualized lettering for each character's speech and thought bubbles. Fidel's lettering is particularly neat and old-fashioned, the former in contrast to his mental state. As another example of visual touchstone, several pages, and especially several first panels of new chapters, focus on long shots of the exterior of a home or other building (Prado, 2012: 11, 36, 43, 50, 83, 89, 114, 116, $127,129,131,141,159,164,181,215)$. This technique orients the reader to the 
action within the building - we know where the characters are. It also gives us visual clues about the scene's location in time, as we see a home increasingly decay and fall into disrepair, for instance (Prado, 2012: 141). Several of these long shots of buildings also represent the moment in which one character leaves the building, highlighting the isolating feeling that accompanies the end of characters' time together in a depopulated area, and recalling again Nora's emphasis on the importance of place in establishing community remembrance (Figure 1).

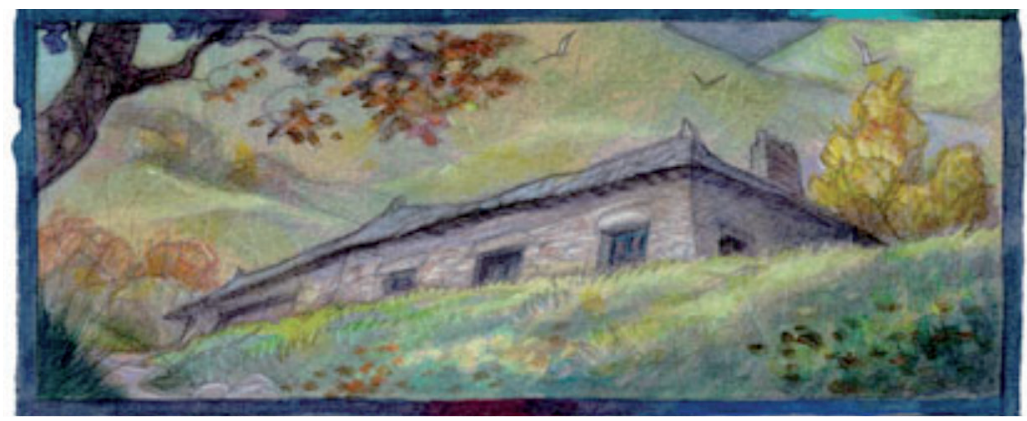

Figure 1. Prado (2012: 18)

The facsimile of an academic article within the pages of Ardalén, titled «Somos quienes recordamos que somos», posits that a specific category of recuerdos (or memories) are the objects (or souvenirs, also a possible translation of recuerdos) we keep to remind us of travel or experiences (Prado, 2012: 60). ${ }^{1}$ Objects within Fidel's home appear to be similarly orienting, but the character's relationship to them is complicated. Objects that seem to contain information about the past, or even to contain memories themselves, include the prints, model boat, compasses, seashells, and other maritime items dispersed around Fidel's house. Fidel, however, has a fraught relationship with these objects, and when Sabela comments that «Es curioso encontrarse con todas estas cosas marineras en medio de los montes», Fidel responds, «La mayoría fueron... un regalo. Y alguno debí de traer de allá, sí... No estoy seguro... No sabría decirle. Sabela, mi memoria, ya se lo dije ayer, es un desastre» (Prado, 2012: 36). Fidel doesn't even know if the objects meant to remind him of travels are really from his own travels. Nonetheless, the objects contain power. They seem to invite sea creatures inside, and we even

1. As an added complication to the generationally relevant meaning of word, Tomás refers to Celia's husband's illegitimate child as a «recuerdo suyo» that he left behind in Maceda with his lover (Prado, 2012: 91). 
see objects from the sea enter the physical space of Fidel's head (Prado, 2012: 158).

Orienting our reading further, Prado inserts other fictionalized, but realistic-looking documentation within the story of Ardalén's two main characters' activities (Figure 2). For instance, the comic includes a full-page reproduction of the cover of another book, titled Atlas Universel, and a full page from the interior of that same book, a copy of a ticket on a boat to Havana, a money order, a letter, an article about memory, a notebook with a poem, a legal proclamation, an article about time, a memo about a boat sinking, an article about flying fish, a letter about political purging, an extract of a book about sea monsters, a psychiatric report, a death certificate, another notebook with information about Fidel's destiny, a full page photographic reproduction, and maps and information about Hurricane Dolly (Prado, 2008: 27-28, 54, 56, 58, 59-62, 84, 117-118, 125-126, 139-140, 152-153, 154, 199-200, 211-212, $224,227,233)$. Many of these documents contain apparently real signatures and seals, and in this presentation they are meant to make simulacra appear bona fide. The inclusion of realistic looking documentation blurs, again, the border between fiction and reality for the reader, but it also orients the reader by inserting the fictional story into a theoretical and academic framework about, and not just of, memory.

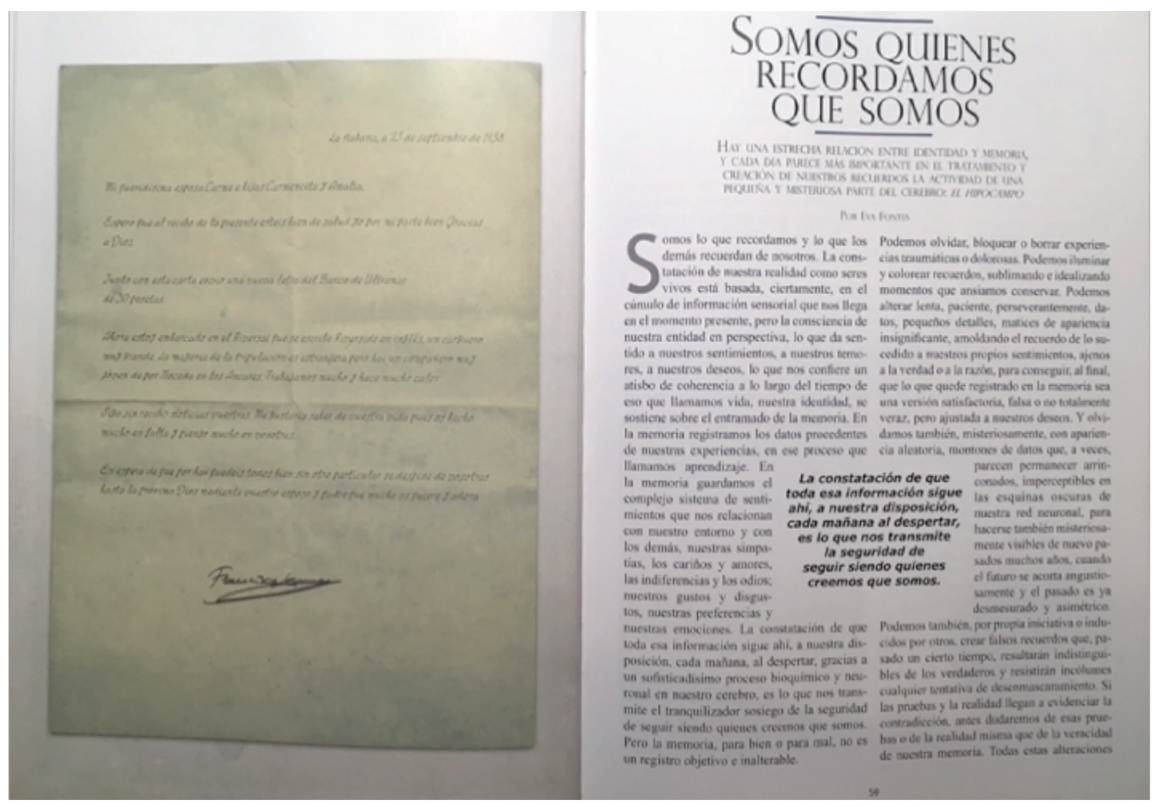

Figure 2. Prado (2012: 58-59) 
There are moments when it seems the memories of Cuba and shipwrecks are indisputably not Fidel's in their origin. For instance, Sabela's closest and most trusted ally, the bar owner Celia, says, «Es cierto, Sabela. Fidel no salió de estos montes, y las cosas que tiene del mar le quedaron de esa tía» (Prado, 2012: 148), and Ramón and Xana's ghosts tell Fidel that «son recuerdos, Fidel... ¡Pero no son tuyos! [...] ¡Son recuerdos ajenos! ¡De otra persona!» (Prado, 2012: 163). Xana postulates that the winds from the Caribbean, have brought Fidel the nostalgia, melancholy, clarity, and memories of others, and that, as if he were drinking them in, Fidel «se empapa como esponja de esos recuerdos ajenos» (Prado, 2012: 164). However, even at the end of the book, after many of the characters have passed on, we readers are still left with doubts about whose memories these are, and perhaps we have stopped caring about determining their origin. They belong to the whole town now, to the younger as well as the older generation, and it is up to everyone to maintain them. Even Sabela, who has arrived recently to the town, and is called an outsider, accepts this charge. A few pages after Xana's aforementioned observation, Sabela's grandfather's ghost finally arrives at Fidel's house, and the two get to know each other, using the recognition of concrete objects like a star necklace and a carved wooden dolphin to solidify their relationship (Prado, 2012: 170-171). Despite the apparent fact that the two men never met in Cuba, Fidel delights in that his lies to Sabela have now become truths.

\section{COLORS AND Borders}

Memories are often shared across generations through inherited objects, written records, and oral stories, among other methods. Since the early twentieth century, one especially popular method for sharing memories is the family photograph. In Ardalén, however, there are very few photographic traces of the past. Sabela has but one photograph of her grandfather, and she shows it to Fidel immediately upon meeting him. When he looks at this photo and hears Sabela mention the Caribbean light and colors, the first tropical image enters the page (Prado, 2012: 23). Unlike the photograph of Sabela's grandfather, which Prado has drawn in sepia tones, the first tropical panel recalls a modern color photograph or a new postcard from the Caribbean. That is, the grandfather's photograph has aged and its image remained frozen, but the mental image that Fidel conjures is as fresh and alive as its Caribbean colors. When Sabela leaves Fidel, he turns on his old radio, hears what appears to be static, wind, or perhaps even whale songs, and we see a flash- 
back to Fidel's childhood in which he studies a world atlas, an early indication that some of Fidel's travels may have been in his imagination. The vibrant colors in the atlas's map of Madagascar echo the image we have just seen of Cuba. Often, when Fidel puts on the radio or listens to a conch shell, aqua shades of ocean air or water drift through his walls and windows (Prado, 2012: 151). The aqua-colored air sometimes carries ghosts with it as well. In other words, almost like a portal, the few existing traces of the past that Sabela does have - her one photograph - elicit ghostly returns in the book and open the door to a flood of other images of and from Cuba. Like the photo, the ghosts who visit Fidel are traces of the past brought into the present, but they are far more alive than the photos.

Symbolized in the blue waves that flow into Fidel's home and the Galician valleys, the book's title refers to a real phenomenon, a long-distance wind that carries far inland the scent of salt and sea from the coast. The word itself is an invention of the author, and for the purposes of the book, the ardalén is made fantastical because it carries with it not just air and smells, but also stories, ghosts, and living creatures of the sea (Figure 3). The fish and whales appear oddly natural in the wet peaks and green valleys of Galicia. In other words, as the border between impossibility and verisimilitude becomes blurry, so does the border between land and sea. Prado's original inspiration for this story, the idea of a shipwrecked man who has never left land, further

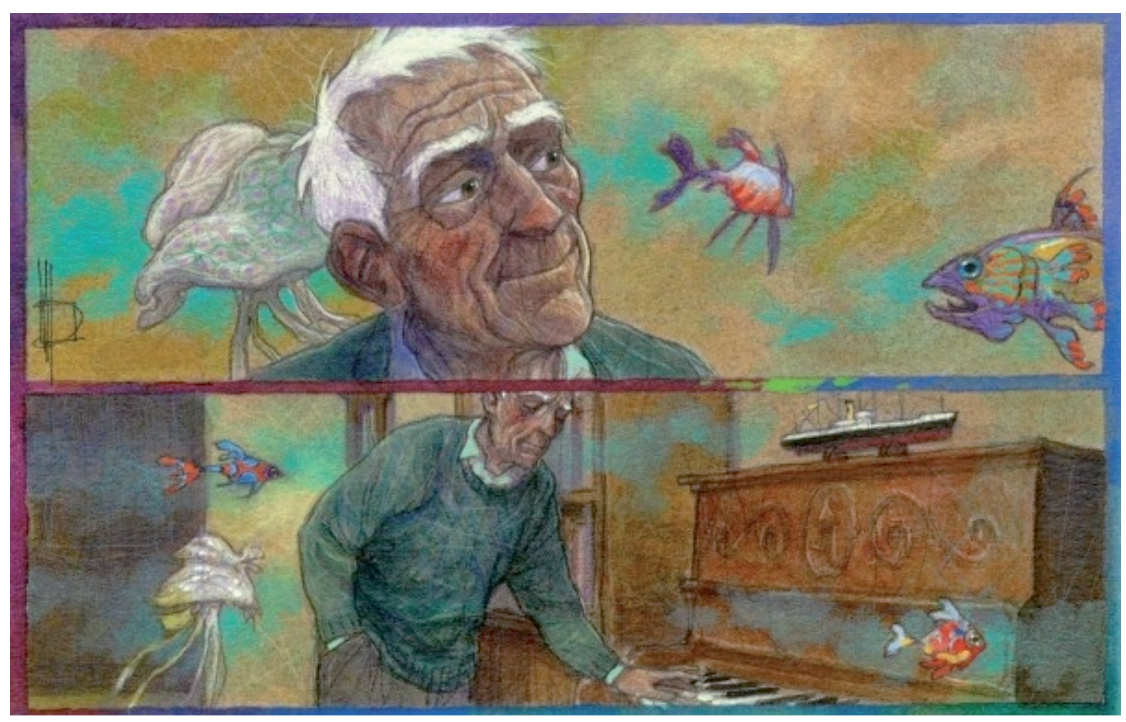

Figure 3. Prado (2012: 180) 
supports the idea of blurred borders between land and sea, as well as between lived experiences and fiction. Likewise, Prado's style, a painted and drawn blend, reinforces this aspect of the story in creating soft and blurry images, colors reminiscent of the sea, and background tones that bleed into the panels at times. Prado's use of pastels and soft bleeds makes more plausible the notion of stories being carried across oceans by the wind, and of the border between sea and land being less clearly delineated than we might expect.

At times, the normally cool colors of the gutters change to indicate a particular mood. For instance, a bold red color appears behind and in between the panels when there is an intense moment of violence or anger, and rainbow fish and Technicolor backgrounds appear in scenes of blissful love; to cite just one page, red is splashed around many of the panels of Tomás's verbal attack on Celia, where he accuses her of being incapable of pleasing her deceased husband, and reveals to Celia that her husband had an illegitimate child (Prado, 2012: 91). The background around the panel that shows Celia's response is similarly colored, as she shouts «¡Callad ya, víboras! [...] ¡Si os mordéis la lengua morís envenenados! ...¿¡Cómo podéis ser tan miserables?!» (Prado, 2012: 95). This tension and use of angry red foreshadows a later scene where Tomás will assault Sabela and threaten to murder her (Prado, 2012: 207-208).

Curiously, and relevant to the discussion of visual borders, it is in the panel where Fidel explains the complicated relationship of his memories to reality that an object (specifically, a falling autumn leaf, an object of the land) breaks through a panel border for the first time (Prado, 2012: 37). Later on, water and sea creatures also splash forth from within the drawn panels and into the gutters. When Fidel tries to tell Sabela about his memories of having survived three shipwrecks, for instance, the past invades his home. Blue streaks appear inside Fidel's kitchen, carrying off items from the counter, as he explains «Un naufragio es una cosa terrorífica. El océano ya es inmenso cuando está tranquilo, pero cuando se pone bravo parece que se va a salir del mundo» (Prado, 2012: 40). On these pages, we see an image of the young Fidel for the first time (Figure 4). When he remembers the enormous waves, we see his terrorized face, mirrored in the older face of the same man on another panel; it is the same face, the same man, with the same expression, but with dark hair and fewer wrinkles (Prado, 2012: 40). In a technique frequently utilized in Paco Roca's renowned Arrugas, a story of dementia and aging, the past and the present version of the character exist in parallel positions, indicating the messy relationship between them (Roca: 2007). Visually, we can see that the past continues to exist within and around the present. 


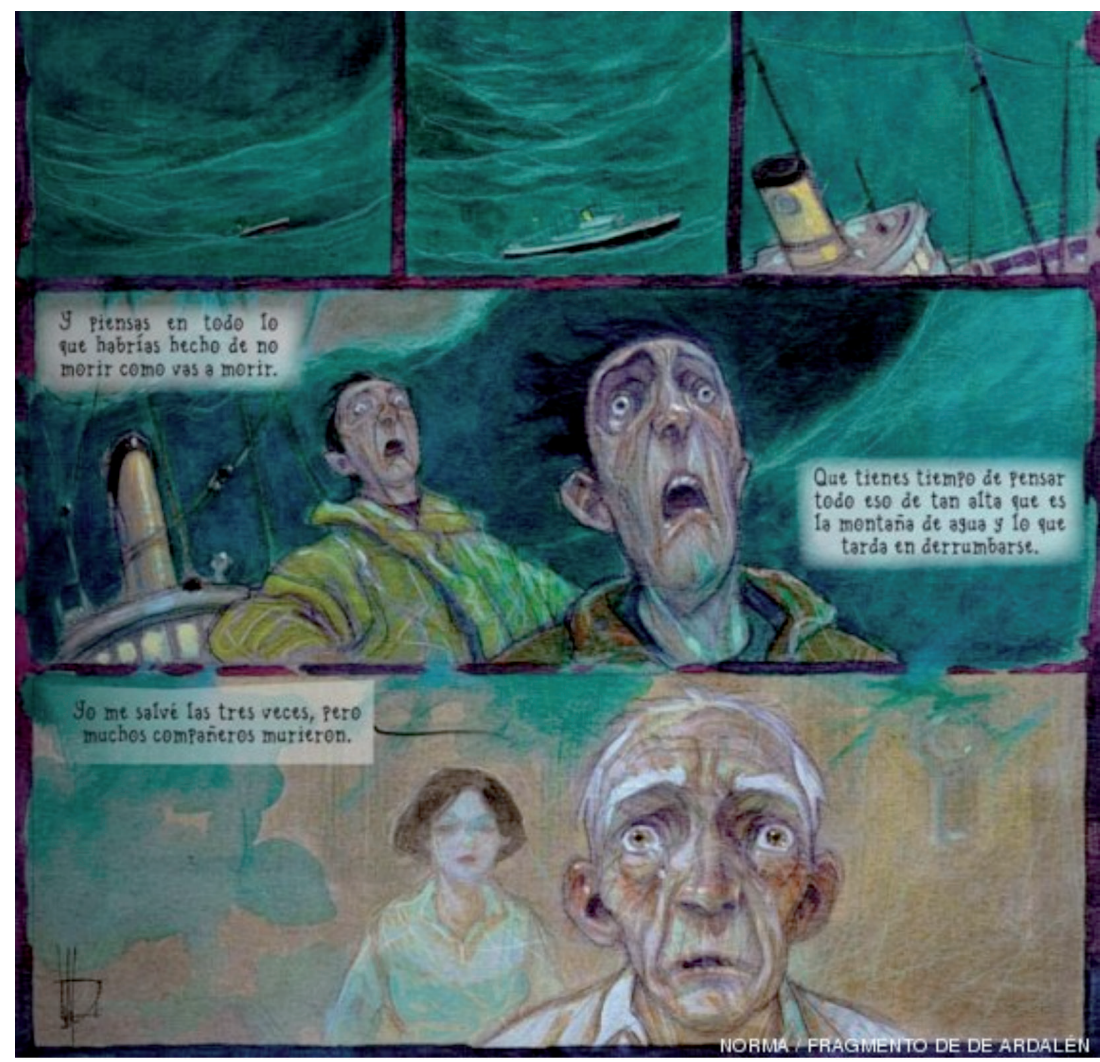

Figure 4. Prado (2012: 41)

Household objects also serve as catalysts for bringing the past back; listening to a shell brings Fidel's deceased shipmate Ramón back to him (Prado, 2012: 44). It is well known that people believe they can hear the sound of the sea in a conch shell, which is exactly what Fidel does, but in his case, he also hears the shell say, «Buenas tardes, Fidel» into his ear and Ramón's ghost enters the room (Prado, 2012: 44). The conch shell becomes even more interesting when we realize that Xana, the blonde woman whose spectral image had appeared along with the sounds of the radio, is responsible for refilling the shell with seawater when Fidel has exhausted its sounds (Prado, 2012: 50). The shell comes from the sea, of course, but it also brings people back from the bottom of the sea, and apparently contains actual seawater rather than just the echo of the listener's pulse. In an additional resonant metaphor, Ramón accuses Fidel of trying to «beber la tristeza a tragos», which suggests that Fidel thirsts for, but suffers when he absorbs, the water (the past) around him (Prado, 2012: 81). Finally, we 
are left to understand that Antonio, whose memories the ardalén has carried to Fidel's mountain home, was killed and thrown into the Caribbean waters, so his blood likely mixed with the seawater on the wind (Prado, 2012: 232). ${ }^{2}$

The ocean's sounds and winds bring creatures small and large to the Galician mountains. Fidel believes that the sound of the wind through the eucalyptus - likely the ardalén in particular — is the sound of whales singing, and so he sits on a particular spot in the mountains on windy days to see them float through the air. The first time that the whales arrive, Fidel shares their witness with Rosalía, his (or more likely, someone else's) former Cuban lover. The book suggests that Rosalía is someone else's former lover because she calls Fidel Antoniño instead of Fidel, and now she appeases him saying, «Mira, mi niño, si quieres llamarte Fidel, yo te llamo como tú quieras» (Prado, 2012: 71). In another scene in which Fidel is alone in the Galician mountains awaiting the whales, a boat that resembles the model in Fidel's home appears, this time full-sized. Recreating his terrifying memory already related to Sabela, this boat also sinks in front of Fidel, causing him to bury his head in his hands (Prado, 2012: 100). On this page, and although Fidel had been sitting on land mere moments before, the seawater transcends, spilling over the black borders of the panels and the page, signaling that the memory of shipwreck cannot be contained, either in time or in space. In addition to utilizing techniques that are specific to the comics medium, in all of these elements - the emotively colored backgrounds, the visual coexistence of past and present, the physical manifestation of a wind that carries memories, and the use of gutter lines as metaphor for other border crossings, Ardalén is fantastic. This approach to fantastic memory is even more interesting when considered in the context of Spain's recent obsession with historical memory.

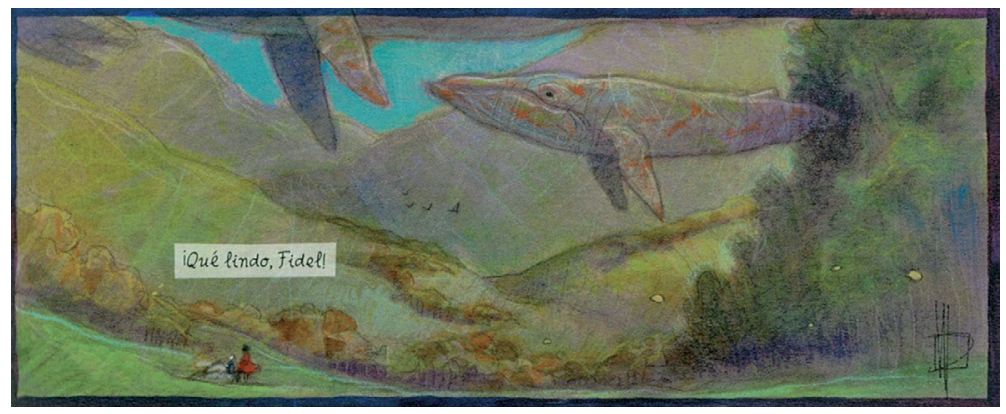

Figure 5. Prado (2012: 71)

2. The metaphor of blood staining the water recalls the impossibility of erasing Spain's bloody and colonial past in the Caribbean as well. 


\section{The Margins of Historical and Personal Memory in a Fantastic} Comic

In an interview with his publishing house, Prado describes Ardalén's story as having two parts: one fantastic or bewildering side that always remains intertwined with the other, realistic side. He notes that without the other, either one of these storylines would be completely different, and that in weaving them together, the book becomes both more disturbing and more moving (Norma Editorial: 2012). Here, the terms Prado uses to describe this comic echo those Todorov established in his classic description of the indivisibility of possible and impossible elements in the fantastic: «In a world which is indeed our world, the one we know (...) there occurs an event which cannot be explained by the laws of this same familiar world. (...) The fantastic occupies the duration of this uncertainty. Once we choose one answer or the other, we leave the fantastic for a neighboring genre, the uncanny or the marvelous» (1975: 25). In both Todorov's and Prado's words, the tension between irrational elements and a familiar universe makes the reader doubt the possibility of definitive margins between them.

Adding to his consideration of the reader experience, Prado goes on to compare the book to:

una caja, encontrada en el desván de los abuelos, en la que hay alguna foto de familiares y amigos casi olvidados, algún objeto curioso, documentos de hace muchos años... Y a partir de todas esas cosas acabamos construyendo un 'todo' posible, una historia. Es como si el lector tuviese acceso a un expediente con documentos que van dando informaciones complementarias de la historia que va conociendo, y puede construir así una narración más rica y con más matices. (Norma Editorial, 2012: n.p.)

In other words, the reader's position vis-à-vis the discovery of information is similar to Sabela's. Both are trying to build a coherent story from scraps of information. Sabela explains this position to Fidel when she first meets him: «Yo, de pequeña, fui encontrando huellas de él... olvidadas o escondidas: una foto, alguna de las cartas... Ésta es la única imagen suya que tengo» (Prado, 2012: 22). The word huellas, traces, or footprints, is also intriguing as an image of memory. As already mentioned, one of the lasting metaphors for memory is that of the wax tablet, where impressions of past events remain. Furthermore, the image of the box of souvenirs or documents is also underlined by Fidel on the following page, where he says, «Mi cabeza es un cajón embaru- 
llado» (Prado, 2012: 24). Both of the major characters lack precise information about the past, as do the readers, and although our doubt is never resolved, impressions and patterns do begin to emerge for readers and for the characters. The active participation of the reader in building the story also parallels the comics medium more generally because one of the most basic characteristics of comics is their use of panels that generally represent discrete moments, and the reader, in creating a smooth connection between panels is also implicated in constructing the story (McCloud, 1994: 68-69). About this, Scott McCloud famously wrote «I may have drawn an ax being raised... but I'm not the one who let it drop...that, dear reader, was your special crime» (1994: 68).

Specific design choices metaphorically connect Sabela's and the reader's experiences as well. For instance, shortly after a full-page reproduction of the sepia photo of Sabela's grandfather, we are in Sabela's position, looking down at two hands that are hers, but because of the angle of the panel, could be the reader's. These hands now hold another photograph: a couple smiling and embracing. The next panel shows a close-up of Sabela's crying face, and then cuts back to the same photo, now torn into pieces (Prado, 2012, 33). The intimate point of view of these panels creates empathy for Sabela in the personal crisis brought on by the breakup of her marriage. A few pages later, on a wordless page, Prado masterfully exploits the comic medium in four wide and wordless panels in landscape orientation (Prado, 2012, 35). Each of the four panels depicts movement in our perspective. First, the top panel shows a desk with some objects on top. Second, we see the torn photograph of Sabela and her ex-husband. Third, we see through the window above the desk, and fourth, we zoom up above the hills beyond the window to see Fidel's isolated country home. These design choices both increase our identification with Sabela and locate her in the context of an isolated town in northwestern Spain (Figure 5).

Through parallels between the fictional experience of Sabela's search for the truth about her grandfather, and the reader's own assembly of the story of her search, Ardalén comments on the impossibility of knowing the truth in personal memory with implications broader than just one fictional woman's crisis. This comic was written after almost two decades of intense debates around the recovery of historical memory in Spain, wherein the past once thought buried and silenced insisted on popping up in the present; Jo Labanyi called this tendency, which started in the late 1990s, a «memory boom» (Labanyi, 2007: 94). More broadly, following on the heels of its (much-debated) pact of forgetting, Spain is also one of many countries that 


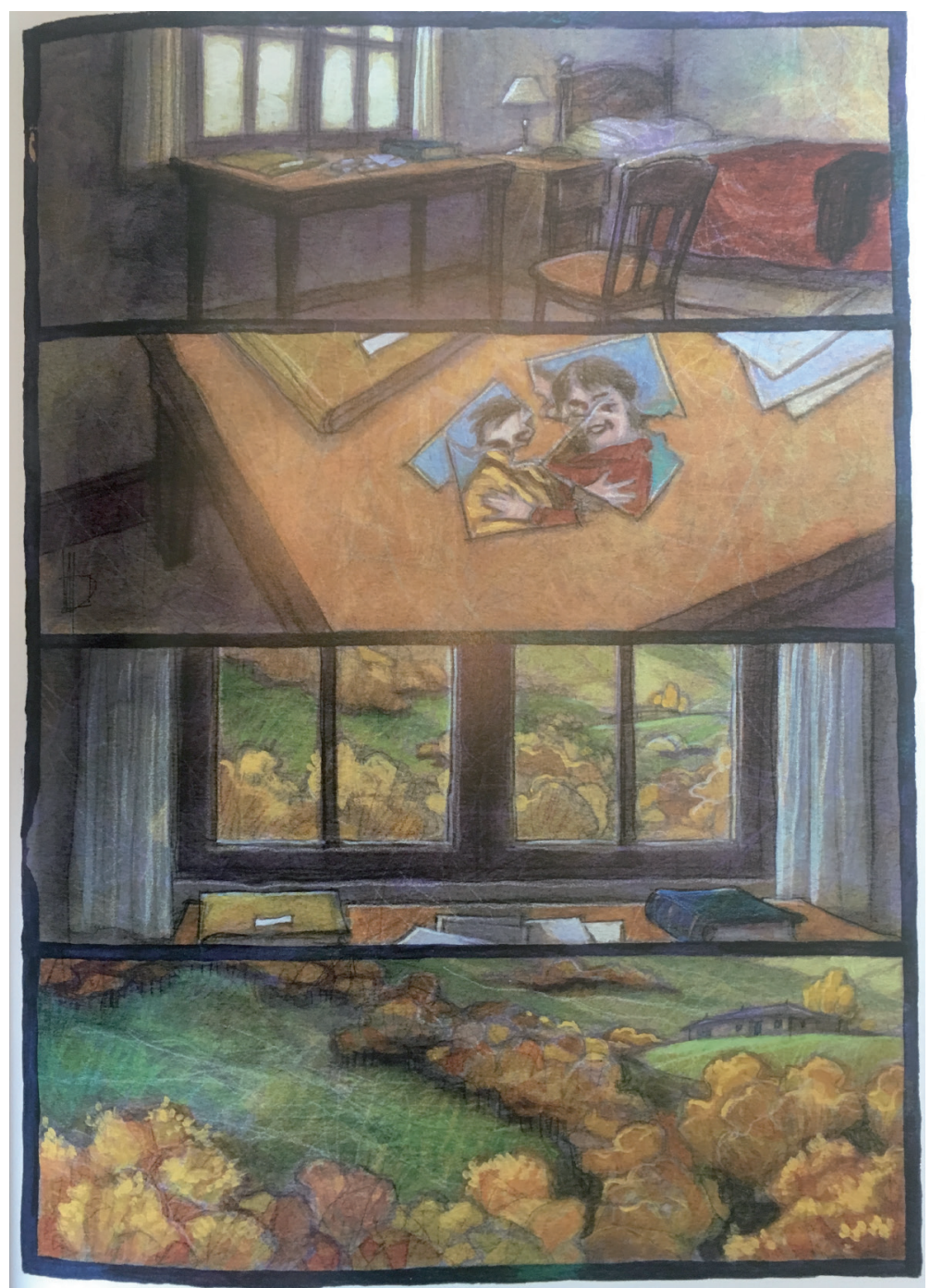

Figure 6. Prado (2012: 35)

participated in a global search for restorative justice in the early $21^{\text {st }}$ century. Anne Whitehead's critical guide to memory ends with a reflection on the global flood of public apologies and searches for restorative justice that defined the first decade of the $21^{\text {st }}$ century. She notes that these trends «aim to promote healing and reconciliation in the aftermath of political violence» but that «Taken together, (...) they also suggest that a discursive shift is beginning to take place from memory to forgetting» (Whitehead, 2009: 154). I would ar- 
gue that this is not so for Ardalén, where, instead this book marks a discursive shift from personal memories that represent a shared experience, to a blurrier and more theoretical study of memory that transcends the divide between the personal and the collective.

Spain's Socialist government declared 2006 the «Year of Historical Memory» and the Congress of Deputies passed what the media termed la Ley de Memoria Histórica in 2007 (see Labanyi, 2008). These laws, which are insufficient and too slowly implemented for many of their supporters, condemn Franco's regime, recognize the rights of those who suffered during the Civil War, abolish laws passed during the regime to dictate sentences, provide better financial benefits to the families of the victims of the dictatorship, allow occupation of land to identify mass graves, force local authorities to remove symbols of the Franco regime, ban political rallies at the Valley of the Fallen, and provide free access to public documents and files (Beaumont, 2007: n.p.). Since their controversial passing, these laws have seen cuts in funding, and the Franco Foundation has announced awards for refusing to comply, while public places continue to be renamed, and debates still swirl around the desirability of continuing to literally unearth graves and metaphorically unearth past crimes. By the time the 2007 law was passed, «The flood of novels set in or after the civil war also seems to have abated» (Labanyi, 2008: 119). Still, questions of memory, collective memory, intergenerational memory, and their representation in various mediums continue to provoke debate, and Ardalén introduces a new, not-quite-apolitical, but also not overtly political perspective to these debates.

Within this context, we might do well to remember that both Sabela's search and much of the debate about historical memory in Spanish politics are motivated by a lack of concrete information about, and intentional silencing of, specific elements of the past. In the case of the book, Sabela lacks information because of her grandmother's attempt to erase all traces of the man who left his family behind. It is precisely because Sabela is denied access to her own past that she looks for it in a moment of crisis, following scant traces of information taken from letters and other documents to guide her. Sabela's reasons for seeking information about her grandfather are personal, but also shared by many others. Her comment to Celia that «lo único que nos queda es nuestro pasado [...] Esas cosas que nos ayudan a creer que hay algo detrás de nosotros» (Prado, 2012: 76) is reflected in the memory obsession of the early twenty-first century globally, and especially in Spain. ${ }^{3}$

3. Merino and Tullis observe a similar concern in Arrugas, which they write, «does not deal specifically 
Ardalén is one of a noteworthy group of Spanish comics that represent, recover, and mourn the loss of historical memory. ${ }^{4}$ Like Ardalén, several of these books were also winners of the Spanish National Comics Prize (established in 2007). Among those with much critical acclaim are Miguel Ángel Gallardo's 1997 Un largo silencio, Carlos Giménez's 2007 collection Todo Paracuellos, Felipe Hernández Cava and Bartolomé Seguí's 2008 Las serpientes ciegas, Antonio Altarriba and Kim's 2009 El arte de volar, and Paco Roca's 2013 Los surcos del azar. For their parts, both Altarriba and Gallardo appropriate their fathers' voices, speaking in the first person for an elderly or recently deceased parent. Altarriba writes that the life of his father, spanning nearly all of the twentieth century, is also closely tied to the concurrent history of Spain. It is, he writes: «la de muchos españoles sin tierra, sin trabajo, sin pan y sin techo (...) No tiene nada de excepcional y por ello es más interesante, ya que él solo es uno más entre los millones de españoles que vivieron cuando la Historia les trajo: el fin de la Dictadura de Primo de Rivera, la caída de la Monarquía, la II República, la Guerra Civil, el régimen de Franco, la nueva Monarquía, la Transición» (Altarriba, 2008: 7). ${ }^{5}$ Giménez explains that one of his motivations for writing Paracuellos was that «que fueran considerados, no solamente como la historia de unos colegios raros y perversos, sino además, también, como una pequeña parte no muy importante en términos generales, pero en términos particulares, para los que nos tocó vivirla y para nuestros familiares, suficientemente importante como para querer dejar constancia de ella» (2007: 13). In both of these comments, and in many of these other memoir-hybrids, paratextual information similarly emphasizes the explicit wish that the publication connect a personal memory to the broader experience of the Spanish post-war.

While these comics confront memory from many angles, none does so quite like Ardalén, which interweaves personal, fantastic, and theoretical approaches to memory. In so doing, it draws a blurry line between personal experience and historical memory. As Labanyi has written, the preamble to the Ley de Memoria Histórica «insists that memory is a private matter» but «fails to acknowledge that "historical memory" is a form of collective and not personal memory, quite apart from the fact that citizens have the right to express

with the Spanish Civil War, [but] is very much centered around the concept of memory and its role in both constructing and maintaining identity» (223).

4. See Matly (2014) for an overview of earlier comics that represent the war and Matly (2015) for a broader overview.

5. See Mitaine (2012). 
their personal memories in the public sphere» (2008: 120). Unlike many of the aforementioned comics that deal with historical memory, Ardalén introduces a theory of personal and also collective memory, as indicated by the possibility of transference of memories across continents and between individuals. Whereas all of these other comics explicitly connect an individual's memoir (fictionalized or not) to a shared broader experience, Ardalén goes further in bringing doubt to the very existence of a line between the personal and the collective. For Ardalén, this line and many others are blurry. It is essential to note that Ardalén moves beyond the tropes of victims and abusers, the black and white, good and evil simplicity with which so many historical fictions paint the Civil War and post-war. ${ }^{6}$ It is also worth mentioning again the words with which this article began: Prado intentionally makes his characters and his stories complex.

In Ardalén, the ghost of Ramón calls oblivion the final and definitive shipwreck (Prado, 2012: 162). Tellingly, Fidel and Sabela are both saved from this definitive shipwreck with the book's resolution, which suggests the importance of maintaining practices of collective remembrance. At the end of Ardalén, with Tomás dead, Fidel and Sabela are welcomed into the community of the bar. With good humor, the other villagers shout, «Siéntate aquí con nosotros, Fidel» and «ven a sentarte y cuéntanos tú, mujer», signaling that the community has moved on from the time of Tomás's reign of terror (Prado, 2012: 217-8). The two main characters are invited to sit together and tell stories; characters lacking in memories and social interactions at the outset of the book now have a community with which to practice remembrance. Furthermore, when Fidel passes on, Sabela adopts his ghosts - including those who originated in the memories of others - saving them all from the «definitive shipwreck» of oblivion. She cleans his old house, making the souvenirs that remain there shiny and bright (Prado, 2012: 241), and adding a few photos of her own. She continues to allow the ardalén to bring sea creatures and ghosts back to the house, and she visits the mountains to see the whales that arrive on the wind.

A book of and about blurry categories, Ardalén suggests the impossibility of knowing the truth of the past. Prado draws blurred margins, both literally and metaphorically, which capitalizes on the uneasiness between verisimilitude and realism in the fantastic. He introduces visual metaphors about memory and identity, and the comic ends with the inheritance of responsibil-

6. Merino and Tullis note a similar element in Un largo silencio, wherein there are «also moments of human solidarity that managed to trump a vast ideological divide» (2012: 219). 
ity. Sabela will provide ongoing attention to Fidel's ghosts and sites of memories, even if the memories weren't his (and certainly were not hers) to begin with. This happy adoption of the burden of memory, across generations, across life and death, across land and sea, and across time and space, leaves the reader to conclude that it is necessary to maintain the legacy of those silenced and buried, so that their memories live on.

\section{BIBLIOGRAPHY}

Altarriba, Antonio and Kim (2009): El arte de volar, Ediciones del Ponent, Alicante.

BeAumont, Peter, and Javier Espinosa (2007): «Spain fights civil war's last battle» in The Guardian, 2007, available at <http://www.guardian.co.uk/world/2007/ nov/04/spain.peterbeaumont> [accessed 24 May 2017].

BENET, Vicente (2007): «Excesos de memoria: El testimonio de la Guerra Civil española y su articulación fílmica», Hispanic Review, 75, pp. 349-363. $<$ https:/ / doi.org/10.1353/hir.2007.0027>

Derrida, Jacques (1981): «Plato's Pharmacy», in Dissemination, trans. Barbara Johnson, University of Chicago Press, Chicago, 1981, pp. 61-172.

Gallardo, Miguel Ángel (1997): Un largo silencio, Astiberri, Bilbao.

Giménez, Carlos (2007): Todo Paracuellos, DeBolsillo, Barcelona.

Gravett, Paul (2010): 1001 Comics You Must Read Before You Die, Universe, New York. Halbwachs, Maurice (1980): The Collective Memory, Harper and Row, New York.

Hernández CAVA, Felipe, and Bartolomé SEguí (2008): Las serpientes ciegas, BD Banda, Madrid.

Khoury, Jorge (2009): «The World of Miguelanxo Prado», in Comic Book Resources, 2009, available at <http://www.cbr.com/254453-2/> [accessed 14 December 2016].

LABANYI, Jo (2007): «Memory and Modernity in Democratic Spain: The Difficulty of Coming to Terms with the Spanish Civil War», Poetics Today, Vol. 28, No. 1, pp. 89-116. <https://doi.org/10.1215/03335372-2006-016> (2008): «The Politics of Memory in Contemporary Spain», Journal of Spanish Cultural Studies, Vol. 9, No. 2, (July 2008), pp. 119-125. <https://doi. org/10.1080/14636200802283621>

MAtLy, Michel (2014): «El cómic español y la Guerra Civil: Transición y primera década de democracia - 1976-1992», Tebeosfera, 12, available at <https: / /www.tebeosfera.com/documentos/el_comic_espanol_y_la_guerra_civil_ transicion_y_primera_decada_de_democracia_-_1976-1992.html> [accessed 13 May 2017].

(2015): «Dibujando la Guerra Civil. Representación de la Guerra Civil (19361939) en los cómics publicados desde 1976», Hispania Nova, 13, pp. 99-125, en <http:/ / www.uc3m.es/hispanianova> [accessed 13 May 2017]. 
McCloud, Scott (1994): Understanding Comics: The Invisible Art, Harper Perennial, New York.

Merino, Ana, and Brittany Tullis (2012): «The Sequential Art of Memory: The Testimonial Struggle of Comics in Spain», Hispanic Issues Series, vol. 11, available at <http:/ /hdl.handle.net/11299/184372> [accessed 13 May 2017].

Mitaine, Benoit (2012): «Memorias dibujadas: la representación de la Guerra Civil y del franquismo en el cómic español. El caso de Un largo silencio», Georges Tyras y Juan Vila, Memoria y testimonio. Representaciones memorísticas en la España contemporánea, Verbum, available at <http:/ / www.verbumeditorial.com/ es/> [accessed 13 May 2017].

NorA, Pierre (1989): «Between Memory and History: Les Lieux de Mémoire», Representations, No. 26, pp. 7-24. <https://doi.org/10.2307/2928520>

Todorov, Tzvetan (1975): The Fantastic: A Structural Approach to a Literary Genre, Cornell UP, New York

Norma Editorial (2012): «Entrevista a Miguelanxo Prado», available at <http:// www.normaeditorial.com/Ardalen/entrevista.html> [accessed 13 May 2017].

Prado Miguelanxo (2012): Ardalén, Norma, Barcelona.

RocA, Paco (2007): Arrugas, Astiberri, Bilbao. (2013): Los surcos del azar, Astiberri, Bilbao.

Whitehead, Anne (2009): Memory, Routledge, New York. 